\title{
Gelişmekte Olan Ülkelerde Doğrudan Yabancı Yatırımları Belirleyen Temel Unsurlar
}

\section{Hayriye Başcı NUR ${ }^{1}$}

İktisadi ve İdari Bilimler Fakültesi Dergisi

Cilt:32, Sayl:2, Yll:2017, ss. 15-45

\section{İlkay DİLBER ${ }^{2}$}

$\ddot{o} z$

Küreselleşme sürecinin ortaya çıkardĭ̆g en önemli olgulardan biri, ülkelere orta ve uzun vadeli sermaye ve teknoloji getiren doğrudan yabancl yatırımlardır (DYY). Araştırmanın amacı, gelişmekte olan ülkelere yönelik DYY'yi çeken belirleyicilerin neler olduğunun açıklanmasıdır. Bu amaçla DYY kavramı üzerinde durulmuş ve DYY'nin temel belirleyicileri irdelenmiştir. 18 gelişmekte olan ülkeye ait DYY girişleri üzerinde etkili olduğu düşünülen 12 farkl değişken, 1996-2014 dönemi için panel veri yöntemiyle analiz edilmiştir. Yapılan çalışma sonucunda, yolsuzluk kontrolü, dışa açıklık oranı, teknoloji, toplam işgücü ve hukukun üstünlüğ̈̈ değişkenlerinin DYY girişlerini olumlu yönde etkilediği, borç stoku, gayri safi sabit sermaye ve altyap değişkenin ise DYY girişlerini olumsuz yönde etkilediği sonucuna varılmıştır.

Anahtar Kelimeler: Doğrudan Yabancı Yatırım, Gelişmekte Olan Ülkeler, Panel Veri.

Jel Sinıflandırma Kodları: E22, C33.

\section{The Determinants of Foreign Direct Investment in Developing}

\section{Countries}

\begin{abstract}
One of the most important phenomenon of globalization process, is foreign direct investments (FDI) that brings medium and long term funds and technology to the countries. The main purpose of this research is to explain the specifications of the developing countries that attract foreign direct investments. For this purpose, the concept of FDI was being focused on and the determinants of FDI were examined. 12 different variables of 18 developing countries which are considered to have an effect on FDI inflow in 1996-2014 of were analyzed with panel data method. At the end of the study we concluded that while control of corruption, openness to trade, technology, total labor and rule of law variables affects FDI inflows positively and total debt service, gross fixed capital formation and infrastructure variables affects FDI negatively.
\end{abstract}

Keywords: Foreign Direct Investment, Developing Countries, Panel Data Analysis.

Jel Classification Codes: E22, C33.

${ }^{1}$ Araş. Gör. Dr., Celal Bayar Üniversitesi, İktisadi ve İdari Bilimler Fakültesi, İktisat Bölümü, hayriye.basci@cbu.edu.tr

${ }^{2}$ Doç.Dr., Celal Bayar Üniversitesi, İktisadi ve İdari Bilimler Fakültesi, İktisat Bölümü, ilkay.dilber@cbu.edu.tr 


\section{GİRIŞ}

\section{H.B.NUR -İ.DİLBER}

Dünyada küreselleşme süreci öncesinde yeterince ilgi görmeyen yabanc1 sermaye, kalkınmaya olan katkısının anlaşılmasıyla birlikte gelişmiş ve gelişmekte olan tüm ülkelerin ilgi odağı haline gelmiştir. Küreselleşmeyle birlikte, ekonomi ve ticarette liberalleşme eğilimleri hız kazanmış, sermayenin serbest dolaşımı artmış ve ticaret serbestleşmiştir. Bu süreçte günümüz toplumlarında üreticilerin yalnızca kendi ülkelerinin piyasalarında etkinlik göstermesi beklenmemelidir. Diğer ülkelerin piyasalarından da yararlanmak amacıyla yabancı bir pazara girmeyi düşünen firmanın önünde, o ülkeye ihracat yapmak dışında farklı seçenekleri bulunmaktadır. Bunlardan biri, piyasasına girmek istediği ülkedeki firmaya, kendi teknolojisini ve marka ismini kullandırarak, lisans anlaşması yapmaktır. Bir diğeri yabancı piyasaya doğrudan sermaye yatırımı yaparak giriş yapmaktır.

Bir şirketin üretimini, kurulu bulunduğu ülkenin sınırlarının ötesine yaymak üzere, ana merkezinin dışındaki ülkelerde üretim tesisi kurması veya var olan üretim tesislerini satın alması doğrudan yabanc1 yatırım (DYY) olarak tanımlanmaktadır. DYY'ler giriş yaptıkları ülkelerde sağladıkları olumlu değişimler yönünden önemle üzerinde durulan konulardan biri haline gelmiştir.

Ekonomik krizlerin olduğu ve istikrarsız konjonktürel dalgalanmaların yaşandığı yıllar dışında DYY girişi sürekli artış eğilimi içindedir. Özellikle gelişmekte olan ülkeler (GOÜ), DYY'yi ülkelerine çekme konusunda büyük bir ivme kazanarak 2014 yılında gelişmiş ülkelerden daha fazla pay almıştır. Birleşmiş Milletler Ticaret ve Kalkınma Konferansı'nın 2015 Dünya Yatırım Raporu'na göre, gelişmekte olan ülkeler, dünya DYY'sinin \% 55'ini almayı başarmıştır. Kalkınmanın önemli bir göstergesi olarak görülmesine karşın DYY'nin ekonomik etkilerini tam olarak ölçmek zordur. DYY’nin ülke ekonomisi üzerindeki etkileri birbirinden farklı faktörlere bağlıdır. Yatırımın yapıldığı sektöre, yatırımın türüne, yabancı firmaların ev sahibi ülkeye karşı tutumuna ve ülkedeki koşullara göre değişkenlik göstermektedir. Bunlara göre DYY’nin giriş yaptığı ülkelere olumsuz olabilecek etkileri de vardır. 
Sermaye sahibi ülkelerin neden DYY yaptıkları ya da GOÜ'lerin neden DYY almak istedikleri dışında yazında öne çıkan konulardan biri de DYY'nin belirleyicileridir. Daha açık bir ifade ile yatırım yapmak isteyen ülkenin, yatırım yapacağı ülke seçiminde göz önünde bulundurduğu, ev sahibi ülkenin koşulları ile ilgili faktörlerdir. Bu faktörler yatırımın geleceği ile ilgili belirleyici unsurlar taşır. DYY'nin belirleyicileri arasında ev sahibi ülkenin piyasa hacmi, işgücü maliyeti, döviz kuru, vergi oranları, dışa açıklık oranı, mevcut altyapısı, sahip olduğu doğal kaynaklar ve diş ticaret açığı gibi ekonomik faktörler öne çıkmaktadır. Bunun yanı sıra ülkedeki hukuksal ve kurumsal ortamın güvenilirliği, yatırımların taşıdığı politik risklerin varlığı ile özelleştirme politikası gibi politik belirleyiciler bulunmaktadır. Yatırım ortamına ilişkin olan belirleyicilerden ekonomik özgürlüklerin derecesi ve yolsuzluk algısı üzerinde durulurken, ülkenin sosyokültürel yapısına ilişkin faktörler de mevcuttur.

Çalışmanın amacı gelişmekte olan ülkelere yapılan doğrudan yabancı yatırımların belirleyicilerini açıklamak ve yazında da yer alan uygun bir modelle hangi belirleyicilerin DYY girişinde önemli olduğunu tahmin etmektir. Ekonometrik model olarak panel veri analizi tercih edilmektedir. Uygulamada önce, panel veri setlerinde yatay kesit bağımlığı test edilip arkasından serilerin durağanlıkları, birinci ve ikinci nesil birim kök testleriyle sınanmaktadır. Panel veri setinin anlamlılığı ve etkinliği test edildikten sonra, yatay kesit bağımlılığını dikkate alan ve almayan tahmincilerle, eşbütünleşmenin varlığı araştırılmaktadır. Son olarak ise, oluşturulan denklemlerde uzun dönem katsayıları bulunmaktadır.

\section{DOĞRUDAN YABANCI YATIRIMLARIN TEORIKK ÇERÇEVESİ}

Bir firmanın üretimini, kurulu bulunduğu ülkenin sınırlarının ötesine yaymak üzere ana merkezinin dışındaki ülkelerde üretim tesisi kurması veya var olan üretim tesislerini satın alması doğrudan yabancı sermaye yatırımı olarak tanımlanır. Doğrudan yabancı sermaye yatırımı yerine dolaysız yabancı sermaye yatırımı, direkt yatırım ya da doğrudan dış yatırım ifadeleri de kullanılmaktadır. Gerek literatürde gerekse uluslararası kuruluşlar tarafından kabul edilen ve daha sık 


\section{H.B.NUR - İ.DİLBER}

kullanılan terim Doğrudan Yabancı Yatırım-DYY (Foreign Direct InvestmentFDI) ifadesidir.

Doğrudan yabancı yatırımlardaki en belirgin özellik, kısmen veya tamamen şirketin mülkiyetinin elde tutulmasının yanında aynı zamanda onun yönetiminin de denetim altında bulundurulmasıdır. Bir firmanın yönetimde etkiye sahip olma ya da onu denetim altında bulundurma derecesi, şirketin mülkiyetinde sahip olunan hisse oranı tarafindan belirlenmektedir. Yabanc1 yatırımc1 direkt oy gücünün en az \% 10'una sahip olduğu zaman, bu girişim doğrudan yatırım olarak kabul edilmektedir. Bu duruma bağlı olarak yabancı semaye yatırımları şu şekilde de tanımlanabilmektedir: Eğer bir yabancı yatırımcı bir başka ülkede yer alan bir firmanın en az \%10 veya daha fazla hissesine sahip olursa bu tip yatırım DYY olarak addedilmekte, aksi durumda yani $\% 10$ 'dan az ise portföy yatırımı kategorisine alınmaktadır (OECD, 2008:17).

DYY'nin, gelişim sürecine bakıldığında, ağırlıklı olarak Çok Uluslu Şirketler (ÇUŞ) aracılığıyla gerçekleştirildiği görülmektedir. Farklı ülkelerde kurduğu şubelerle aynı anda birçok ülkede birden üretim faaliyetine katılan şirketlere çok uluslu şirket adı verilmektedir (Seyidoğlu, 2001:400). ÇUŞ, üretim faktörlerini birden çok ülkede kontrol edebilen organizasyonlardır. Bir işletmenin çok uluslu şirket olabilmesi için, farklı ülkelerde yavru şirkete sahip olması veya ortak yatırımlara gitmesi vazgeçilmez önkoşuldur. Bu bakış açısıyla, yatırım yapan, ana merkez konumundaki işletme "ana şirket", değişik ülkelerde yapılan yatırımlarla edinilen işletme ise "yavru şirket" veya "şube" olarak isimlendirilmektedir. Ana şirket, şubenin mülkiyetini elinde bulundurmaktadır ve yönetimini de kendi kontrolü altında tutmaktadır.

\subsection{Doğrudan Yabancı Yatırımların Türleri}

Doğrudan yabancı yatırımlarının türlere ayrılmasında, çok uluslu şirketlerin yatırımlarını şekillendiren farklı nedenlerin ve yatırım koşullarının geçerli olması önemli bir etkendir. Çok uluslu bir şirket doğrudan yabancı yatırıma karar verirken, aynı zamanda dış piyasaya giriş biçimini de belirlemek durumundadır. $\mathrm{Bu}$ 
konudaki belli başlı yollar şunlardır (Seyidoğlu, 2001:403): Bir veya daha çok sayıda yerel şirketle ortak girişim kurmak, mülkiyeti tek başına kendisine ait yeni bir bağlı şirket oluşturmak, mevcut bir yerel firma ile birleşmek veya onu satın almak, bir veya daha çok sayıdaki ortak ile stratejik birlik kurmaktır.

Ortak girişim, yabancı yatırımcının, ev sahibi ülkede faaliyet gösteren yerli bir firma ya da devlet kurumları ile ortaklık kurularak yeni bir tesisin kurulması veya mevcut tesisin paylaşılması yoluyla gerçekleşmektedir. Şirket birleşmeleri bir şirketin başka bir şirketi satın alması ya da birden çok şirketin aynı çatı altında bir araya gelmesi durumudur. Ortak girişim ve pazarlama anlaşmalarını öngören stratejik birleşmeler ise bir tür doğrudan dış yatırım benzeridir (Seyidoğlu, 2001: 405). Aralarındaki en önemli fark stratejik birleşmelerde ana şirketler arasında genellikle bir hisse senedi değişiminin yapılmasıdır.

\subsection{Ev Sahibi Ülke Açısından Doğrudan Yabancı Yatırımların Etkileri}

Doğrudan yabancı yatırımlar, hem DYY alan ev sahibi ülke hem de yatırımda bulunan kaynak ülke açısından oldukça önemli etkilere sahiptir. Yabancı sermayenin gittiği ülkelerde yaratacağı etki, iktisat literatüründe uzun süredir tartışılan bir konudur. Yabancı sermayenin, gelişme sürecindeki ülkelere olan etkileri ile ilgili ilk çalışmalar 1960'lı yıllara uzanmaktadır. Rosestein-Rodan (1961)'ın yabancı yatırımların özellikle gelişmekte olan ülkelere olan etkilerini konu aldığı çalışması bulunmaktadır. Bu çalışmada, gelişmekte olan ülkelere yapılan yabancı yatırımların, bu ülkelerdeki yerel sermaye birikimini, daha sonra hiçbir yardımc1 araca gereksinim duymadan korunabilir bir düzeye yükselteceğinden bahsedilmektedir. Ayrıca yabancı sermaye girişi ile ülkeye gelen teknik bilgi sayesinde, mevcut üretim potansiyeline ek ürünler ilave edilecektir. Böylece var olan gelir düzeyinde, daha yüksek tasarruf oranlarına ulaşılacaktır (Rosestein-Rodan, 1961:2).

DYY'nin ev sahibi ülkeye olumlu etkilerinin arasında gelişmekte olan ülkelerin sermaye birikimini hızlandırması, teknoloji ve işletmecilik bilgisini beraberinde getirmesi ve ekonomik büyümeye yardımcı olması bulunmaktadır. Bu yaklaşımla 


\begin{abstract}
H.B.NUR - İ.DİLBER
doğrudan yabanc1 yatırımlar, yoksulluğu azaltacak ve küresel ekonominin etkinliğini artıracak bir araç olarak görülmektedir. Doğrudan yabancı yatırımı destekleyenler kadar olumsuz özelliklerinin çoğunlukta olduğunu savunanlar da vardır. Doğrudan yabancı yatırımın karşısındakiler, doğrudan yabancı yatırımın daha yüksek teknolojik bağımlılığa neden olacağını, yabancı sermayeli şirketlerle rekabet edemeyen yerli firmaların piyasadan çekilmesine yol açacağını ve ödemeler bilançosunda baskı yaratacağını savunmaktadır. Doğrudan yabancı yatırımlarının olumlu etkilerinin yanında, olumsuz etkilerinin de olduğu literatürden de incelenerek görülmektedir. Ancak ülke gerçekleriyle uyumlu ve planlı politikalarla, olumsuz etkilerini azaltmak ve ekonomiye katkısını artırmak olasidir.
\end{abstract}

\title{
3. DOĞRUDAN YABANCI YATIRIM HAREKETLERI
}

Kendi ülkesinden çıkan sermayenin, başka bir ülkede yatırıma dönüşmesi 16 . yüzyıla kadar dayanmaktadır. Ancak ilk somut adımlar sanayi devrimi ile birlikte 19. yüzyılın ikinci yarısında başlamaktadır. Sanayi ülkelerinin ihtiyaç duyduğu madenlerin ve tarıma dayalı hammaddelerin çıkarılması amacıyla merkezden çevre ekonomilere yatırım yapılması ile bu konuda ilerleme sağlanmıştır. Sanayi devriminin öncülerinden olan İngiltere, özellikle az gelişmiş ülkelere yapılan yatırımlar konusunda ilk sırayı almaktadır. İngiltere'yi Amerika Birleşik Devletleri (ABD), Fransa, Almanya, İsviçre, Belçika ve Hollanda izlemektedir (Dunning, 1988:74). Sermaye çıkışlarının kategorileri konusunda ülkeler arasında farklılıklar bulunmaktadır. Avrupa'dan kaynaklanan sermaye çıkışları finansal yatırımları tercih ederken, I.Dünya savaşı öncesinde ABD'den gerçekleşen yatırım çıkışları, doğrudan yabancı yatırım şeklini almaya başlamaktadır. Özellikle Birinci Dünya Savaşı'ndan sonra, yatırımların daha çok ABD'de yoğunlaşmaya başlaması ile ülkenin ön sıralarda yer aldığı görülmektedir. Ancak 1929 Dünya ekonomik buhranı yabanc1 yatırımların azalmasına, hatta mevcut yatırımların tasfiye edilmesine yol açmıştır.

II. Dünya Savaşı, doğrudan yabancı yatırımlar için bir dönüm noktası olmuştur. Savaş sonrasında, yatırımlarla birlikte dünta ticareti artış göstermiştir (Batmaz ve 
Tunca, 2005:70). II. Dünya Savaşı'ndan 1990'l1 y1llara kadar, gelişmiş ülkelerin tamamına yakınında, sağlanan teşvikler ve yapılan tanıtımlar ile doğrudan yabancı yatırımları çekebilmek amaçlanmıştır. Gelişmekte olan ülkelerde ise hakim olan görüş, yabancı yatırımların ülke egemenliklerini tehlikeye sokacağı, ilerleyen dönemlerde gelirden daha çok döviz çıkışına yol açacağıdır. GOÜ tarafından sömürgeciliğin bir aracı olarak görülen yabancı yatırımlar ancak çok katı kurallar ve engellemeler ile izin verilebilecek bir dış finansman aracı olarak kabul görmektedir (DPT, 2000:3). Ancak 90'lı yıllara doğru durum değişmiş, gelişmekte olan ülkelerin birçoğu çeşitli düzenlemeler yoluyla uluslararası yabancı sermaye hareketlerinden daha fazla pay alma gayreti içine girmiştir.

\subsection{Global Doğrudan Yatırım Girişleri}

Zaman zaman dünyada ekonomik konjonktüre bağlı olarak yabancı sermaye hareketlerinde dalgalanmalar yaşansa da, genel bir artış eğilimi gözlenmektedir. 1970'lerde 24 milyar dolar olan DYY girişleri, 1980'lerde 93 milyar dolar, 1990'larda 402 milyar dolardır. 2000 yılında rekor bir artışla 1,4 trilyon dolar uluslararası DYY girişi gerçekleşmiştir. 2001 yılı DYY açısından hızlı bir gerilemenin yaşandığı dönemdir. DYY'ler 2000 yılına göre \% 51 küçülme göstererek 825 milyar dolar seviyesine gerilemiştir. Gelişmiş ekonomilerdeki durgunluk, sınır ötesi satın alma ve birleşmelerdeki gerilemeler yine özellikle ülkelerin bilgi teknolojisi ağırlıklı sektörlerindeki sorunlar ve kısmen de 11 Eylül saldırısı bu düşüşte önemli rol oynamıştır. Buna rağmen gelişmekte olan ülkeler bu olumsuzluktan fazla etkilenmemiştir (UNCTAD, WIR:2002).

2005-2007 y1llarında DYY girişi ortalama olarak 1,5 trilyona yaklaşmaktadır (YASED, 2013:5). İstikrarlı ekonomik büyüme, ülkelerin yatırım rejimlerinde devam eden liberalleşme, finansman koşullarında yaşanan elverişli ortam, ÇUŞ'ların sayılarının ve etkinliklerinin artışı ile birlikte DYY üst üste dört yıl boyunca büyüme yönünde olumlu seyir izlemiştir. 2006 yılı DYY’ler açısından 2000 yılındaki düzeyi yakalayan bir yıl olmuştur. DYY miktarı 1.46 milyar dolar olmuştur. Gelişmekte olan ülkelerin de uluslararası yatırımlarda kaynak ülke konumuna gelmesi, yeniden yatırıma dönüştürülen kazançların artması ve yine 


\section{H.B.NUR - İ.DİLBER}

satın alma ve birleşmelerin artan rolü uluslararası yatırımların bu artışında önemli bir yer almıştır (UNCTAD, WIR:2007). 2007 y1lında DYY girişleri 1.83 trilyon dolar ile 2006 yılına göre \% 30 artışla büyük bir sıçrama yapmış ve 2000'lerin zirvesini görmüştür. Finansal krizin 2007 yılının ikinci yarısından itibaren baş göstermesine karşın üç ana ekonomik grubun (Gelişmiş Ekonomiler- GOÜ ve Güneydoğu Avrupa'nın geçiş ekonomileri- Bağımsız Milletler Topluluğu) DYY girişlerinde artış gözlenmektedir. DYY'deki bu yükseliş büyük ölçüde yüksek ekonomik büyüme ve güçlü kurumların dünyanın birçok yerinde olmasıyla açıklanmaktadır (UNCTAD, WIR :2008).

Fakat 2007 yıl ortasında ABD'de başlayan kriz nedeniyle, bu büyüme sürecinin sonuna gelinmiştir. Global bazda devam eden finansal ve ekonomik krizden, uluslararası doğrudan sermaye akımları da olumsuz etkilenmiştir. Küresel krizin etkisi ile 2008 ve 2009 yıllarında DYY akışında bir zayıflama gözlenmektedir. ÇUŞ'ların karlılık oranlarının düşüşü, şirketlerin elde ettikleri karın daha azını yeniden yatırıma yönlendirmelerine yol açarken, DYY akımlarında, 2003 yılında başlayan artış trendi, 2008 yılında sona ermiştir. DYY akımları, 2008 yılındaki global krizin etkisiyle bir önceki yıla oranla \%14 düşüş göstermektedir. Mali kaynaklara erişim konusunda yaşanan sıkıntılar nedeniyle yatırım yapabilme kapasitesindeki düşme DYY'yi azaltan etkenlerden biridir. Bununla birlikte büyümeye yönelik olumsuz tahminler ve likidite sıkışıklı̆̆ nedeniyle birleşme ve satın alma işlemlerindeki düşüş DYY'yi azaltmıştır (Bal ve Göz, 2010:456).

Şekil 1., 2009 yılından günümüze dünyadaki DYY girişlerinin toplamını göstermektedir. Buna göre 2010 yılında bir önceki yıla göre 1lımlı bir artış gerçekleşmiştir. $\mathrm{Bu}$ artışın nedeni daha çok GOÜ'lere yapılan yatırımların artış göstermesidir. 2010 yılında ilk kez GOÜ’ye ve geçiş ekonomilerine yapılan yatırım toplam DYY'nin yarısından fazladır. Dünya sanayi üretimi ve ticareti, kriz öncesi düzeylere dönerken yine de DYY akımları kriz öncesi ortalamasının \%15, ve 2007'deki tepe noktasının \%37daha aşağısındadır (UNCTAD, WIR:2011). 


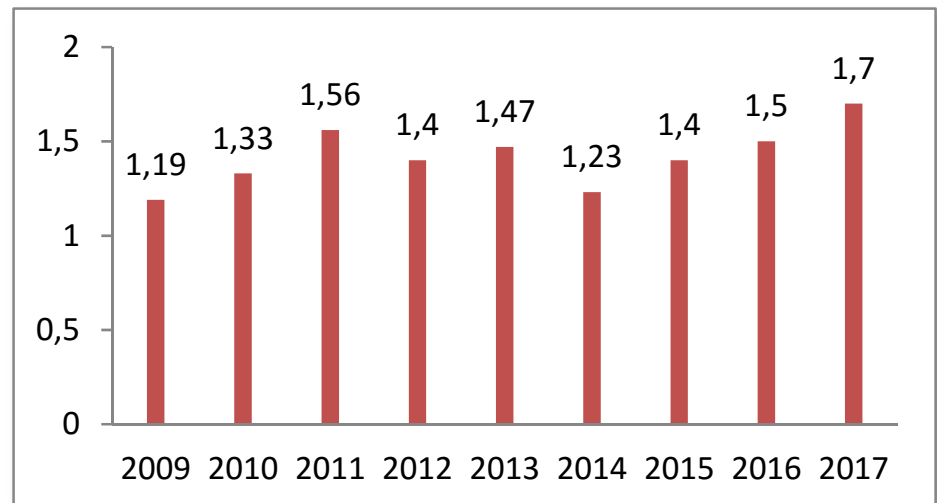

Şekil 1. Global Doğrudan Yabancı Yatırım Girişleri (Trilyon Dolar)

Kaynak: YASED, UNCTAD Dünya yatırım Raporu Lansmanı, 2015 s.3 (2015-2016 ve 2017 yılları UNCTAD tahminleridir.)

2011 yılında \%16,5 artışla 1,5 trilyonu aşan global DYY ile kriz öncesi dönemi ortalaması olan 1,4 trilyon dolar düzeyine ilk defa tekrar ulaşılmıştır. 2012 yılında ise tekrar bir düşüş eğilimi gözlenmektedir. $\mathrm{Bu}$ düşüşe neden olarak, makroekonomik kırılganlık, Avro Krizi, ABD'deki mali uçurum ve Hükümet değişiklikleri sonucu yaşanan siyasi belirsizlikler gösterilmektedir (UNCTAD, WIR:2013).

Global yatırımlar, 2014 yılında bir önceki yıla göre \% 16'lık düşüşle 1,23 trilyon dolara gerilemiştir. Bu düşüşün nedenleri arasında küresel ekonominin kırılganlığı, yatırımcılar için politik belirsizliklerin varlığı ve jeopolitik risklerin yüksekliği gösterilmektedir. 2015 y1lı için DYY akımlarında belirsizlikler devam ediyor olsa da toplam küresel DYY akışlarının \% 11'lik artışla 1,4 trilyon dolar olması beklenmektedir. Gelişmiş ekonomilerde ekonomik büyümenin güçlendirilmesi, düşük petrol fiyatlarının talebi uyarıcı etkisi, uzlaşmacı para politikaları ve yatırımlarda devam eden liberalleşme DYY akımlarını olumlu yönde etkileyecektir. UNCTAD'ın DYY tahminleme yöntemi ile birlikte ÇUŞ'ların geniş çaplı iş anketlerinin sonuçları önümüzdeki yıllar için DYY akımlarında, artış yönlü sinyaller vermektedir. 2016 yılı için tahmin edilen değer 1,5 trilyon dolar ve 2017 yılında ise 1,7 trilyon dolardır. Ancak Euro bölgesinde süregelen belirsizliklerin de 


\section{H.B.NUR - İ.DİLBER}

dahil olduğu siyasi riskler, jeopolitik gerginlikler ve gelişmekte olan ülkelerdeki kalıcı güvenlik açıkları öngörülen iyileşmeyi engelleyebilecektir (UNCTAD, WIR:2015).

\subsection{Gelişmekte Olan Ülkelere Yapılan Doğrudan Yabancı Yatırımlar}

İkinci Dünya Savaşı sonrasında kalkınma çalışmalarına hız veren gelişmekte olan ülkeler, yalnızca gelişmiş ülkelere hammadde satıp sanayi ürünü ve yatırım malı alma şeklindeki dış ticaret ilişkisinin ötesine gitme yollarını aramışlardır. Yurt içi tasarrufların ekonomik kalkınma için yeterli olmaması nedeniyle DYY ihtiyacı belirmiştir. Aynı dönemde GOÜ, yabancı sermayeden korkmak yerine yabancı sermayeyi çekmek için çaba göstermektedir. Yabanc1 yatırımcı için vergi muafiyetleri uygulanmakta, altyapı hizmetleri, pazar önceliği ve tekel hakları sunulmaktadır (Karagöz, 2007:932).

GOÜ'lerde 1980'lere kadar, Keynesyen iktisat politikaları temelinde, düşük faiz ile yüksek yatırım düzeylerine ulaşma ve finansal piyasalara müdahale ederek baskı altına alma politikaları uygulanmıştır. Neo-klasik yaklaşım, böyle bir oluşum için gerçekleştirilen finansal serbestleşmenin sorun çıkarmaması için, öncelikle para piyasası ve kamunun dengesinin sağlanmış olması gerektiğini vurgulamaktaydı. Neo-klasik finansal serbestleşme teorisi çerçevesinde birleşen Washington Konsensüsü yaklaşımı, bu koşulların gerçekleştirilmesi şartıyla, faiz oranlarının serbestleştirilmesinin, finansal araçların arttırılarak finansal sistemin de derinleşme ve etkinlik yaratacağını savunmaktadır. Washington Konsensüsü, 1989 yılında ekonomilerinde reforma giden ülkeler için on maddelik politika önerisinde bulunmuştur. $\mathrm{Bu}$ kurallar mali disiplin, vergi reformu, kamu harcamalarının yeniden yapılandırılması, finansal serbestleşme, tek ve rekabetçi döviz kuru uygulama, ticaretin serbestleşmesi, doğrudan yabancı sermaye yatırımlarına getirilen engellerin kaldırılması, özelleştirme, piyasaya girişin ve rekabetin yeniden düzenlenmesi ve mülkiyet haklarının güvence altına alınmasını içermektedir. $\mathrm{Bu}$ on maddelik politika önerileri, uluslararası kredi kuruluşlarının politikalarını da etkilemiş ve özellikle, 1980 sonrasında IMF istikrar paketlerinin finansal serbestleşme içeren yapısının, 1990'lı yıllarda da devam etmesini sağlamıştır 
Dokuz Eylül Üniversitesi Iktisadi ve İdari Bilimler Fakültesi Dergisi Cilt:32, Sayl:2, Yll:2017, ss. 15-45

(Eroğlu, 2002: 24). Bu ülkelerde 1980 sonrasında, yatırımcıyı koruyucu önlemlerinin alınmasına özen gösterilmiştir. Bu gelişmeler sonrasında özellikle 1990’lı yıllarla birlikte, gelişmekte olan ülkelere yönelik sermaye akımlarında artışlar kaydedilmiştir. Gelişmekte olan ülkeler 1991'de dünyadaki toplam doğrudan yabancı yatırımların \%22,3'ünü, 1994'te \%35,2'sini, 1998'de \%25,9'unu ve 2000 'de $\% 15,9$ 'unu almıştır. 2005 yılından sonra ise dünyadaki yatırım artışı payından GOÜ giderek daha büyük pay almaktadır. Tablo 1., 1970 y1lından günümüze seçilmiş yıllarda dünyadaki DYY girişlerinin gelişmiş ekonomiler, gelişmekte olan ekonomiler ve geçiş ekonomileri arasındaki dağılımını göstermektedir.

Tablo 1. Dünya Üzerinde Doğrudan Yabancı Yatırım Girişleri (1970-2014)

\begin{tabular}{|c|c|c|c|c|c|c|c|}
\hline & 1970 & 1975 & 1980 & 1985 & 1990 & 1995 & 2000 \\
\hline Dünya & 13.257 & 26.396 & 54.400 & 55.835 & 204.896 & 341.537 & 1.363 .215 \\
\hline $\begin{array}{l}\text { Gelişmiş } \\
\text { Eko. }\end{array}$ & 9.491 & 16.858 & 46.978 & 41.748 & 170.213 & 219.772 & 1.125 .227 \\
\hline GOÜ & 3.766 & 9.538 & 7.398 & 14.072 & 34.608 & 117.767 & 232.216 \\
\hline \multirow[t]{2}{*}{ Geçiş Eko. } & 0 & 0 & 24 & 15 & 75 & 3.999 & 5.772 \\
\hline & 2001 & 2002 & 2003 & 2004 & 2005 & 2006 & 2007 \\
\hline Dünya & 684.071 & 591.386 & 551.993 & 682.749 & 927.402 & 1.393 .034 & 1.871 .702 \\
\hline $\begin{array}{l}\text { Gelişmiş } \\
\text { Eko. }\end{array}$ & 460.726 & 414.570 & 337.648 & 389.512 & 565.423 & 930.175 & 1.254 .988 \\
\hline GOÜ & 215.594 & 166.732 & 196.308 & 264.080 & 330.178 & 403.881 & 528.536 \\
\hline \multirow[t]{2}{*}{ Geçiş Eko. } & 7.751 & 10.084 & 18.037 & 29.158 & 31.801 & 58.978 & 88.178 \\
\hline & 2008 & 2009 & 2010 & 2011 & 2012 & 2013 & 2014 \\
\hline Dünya & 1.489 .732 & 1.186 .513 & 1.328 .215 & 1.564 .935 & 1.403 .115 & 1.467 .149 & 1.228 .283 \\
\hline $\begin{array}{l}\text { Gelişmiş } \\
\text { Eko. }\end{array}$ & 787.761 & 652.306 & 673.223 & 828.447 & 678.960 & 696.770 & 498.784 \\
\hline GOÜ & 585.647 & 463.637 & 579.891 & 639.135 & 639.022 & 670.790 & 681.387 \\
\hline Geçiş Eko. & 116.324 & 70.570 & 75.101 & 97.353 & 85.134 & 99.589 & 48.122 \\
\hline
\end{tabular}

Kaynak: UNCTAD Doğrudan Yabancı Yatıım İstatistikleri’nden alınarak tarafımızdan hazırlanmıştır.

2005 yılından sonra GOÜ’ye yapılan DYY payındaki artış göze çarparken, ilk kez 2012 yılında GOÜ ve geçiş ekonomilerine yapılan toplam DYY girişi, gelişmiş ülkelere göre daha fazladır. Gelişmekte olan ülkelere olan DYY akımı 2014 yılında 


\section{H.B.NUR -İ.DİLBER}

681 milyar dolara ulaşarak en yüksek düzeyi yakalamıştır. 2014 yılında, toplam DYY akışının \% 55'i GOÜ'ye yapılmaktadır. ÇUŞ'ların özellikle gelişmekte olan Asya ülkelerine olan yatırımları rekor seviyeye ulaşmıştır. GOÜ’ye giden DYY böylece genişlemiştir. Çin, dünyanın en büyük alıcısı konumuna gelmiştir. Dünya çapında bakıldığında, dünyada en çok DYY alan on ekonominin içinde beş gelişmekte olan ülke bulunmaktadır. Bu ülkeler Çin, Hong Kong-Çin, Singapur, Brezilya ve Hindistan'dır. GOÜ’lere DYY'lerin artışı öncelikle gelişen Asya ekonomilerinin sayesinde olmuştur. Gelişen Asya ekonomileri \% 9 ile tarihsel olarak en yüksek DYY artışı sağlayarak neredeyse yarım trilyon dolarlık yatırım almıştır. Bu oran GOÜ'lerin hepsine gelen toplam DYY'nin 2/3'sinden fazladır. (UNCTAD WIR, 2015:17).

\section{DOĞRUDAN YABANCI YATIRIMLARIN TEMEL BELİRLEYİCILERİ}

Doğrudan yabancı yatırımlar ülkelere giriş yaparken, ev sahibi ülkenin ekonomik, sosyal, kültürel ve politik koşulları ile yatırım ortamına ilişkin düzenlemelerin güvenilirliğine dikkat etmektedir. Özellikle gelişmekte olan ülkeler için önemi yadsınamaz olan doğrudan yabancı yatırımların düzeyini yükseltmek, söz konusu ülkelerin ekonomik büyüme ve kalkınmalarına büyük ölçüde katkıda bulunacaktır. Doğrudan yabancı yatırımı ülkeye çeken faktörler genellikle ev sahibi ülkenin iç dinamiklerinden kaynaklanmaktadır. UNCTAD 1998 yılı Dünya Yatırım Raporu'nda, DYY'yi belirleyen faktörlere ilişkin bir analiz yapmaktadır. Söz konusu belirleyiciler, üç ana başlıkta toplanmaktadır. Bunlar; ekonomik faktörler, yatırım ortamına ait faktörler ve politik faktörlerdir. DYY'yi ülkeye çeken faktörler arasında ekonomik faktörler yoğunluktadır. Piyasa büyüklüğü, doğal kaynaklar, toplam işgücü, fiziki altyapı ve bölgesel entegrasyonlara yönelik anlaşmalar önemli ekonomik belirleyiciler arasındadır. Ekonomik, siyasi ve sosyal istikrarı içine alan politik faktörler, özelleştirme ve vergi politikalarını da içermektedir. Yatııım teşvikleri ve piyasaların şeffaflığı yatırım ortamına ilişkin belirleyicilerdir. 


\section{5. İLGİLİ LİTERATÜR}

Konuyla ilgili ekonometrik modelin ilk örneklerinden biri Dunning (1981) tarafından gerçekleştirilmiştir. Çalışmanın amacı eklektik teorisine dayanarak ülkelerdeki uluslararası doğrudan yatırım pozisyonlarını incelemek ve bu pozisyonlardaki değişmeyi gözlemlemektir. Bunun için 1967-1978 dönemine ait 67 ülkenin verileri kullanılmaktadır. Ülkelerin gelişmişlik aşamaları ve ekonomik yapıları ile DYY'nin belirleyicileri arasında sistematik bir ilişkinin varlığını önermektedir. DYY'yi belirleyen temel faktörler arasında pazar kapasitesinin büyüklüğü, birim emeğin maliyeti, hizmet sektörünün verimliliği ve enflasyon oranı belileyiciler arasında gösterilmektedir.

İlerleyen süreçte DYY'nin belirleyicileri arasında ekonomik değişkenler kadar politik değişkenlerin de yer aldığı ileri sürülmektedir. Agarwal, 1980 yılına ait çalışmasında ekonomik değişkenlerin yanında politik değişkenleri de kullanmaktadır. Politik değişken olarak siyasi alandaki istikrarsızlık ve yabancı şirketlerin ulusallaştırma tehdidi değişkeni alınmaktadır. Ekonomik değişkenleri ise piyasanın hacmi, yatırımlara verilen teşvikler, büyüme ve enflasyon oranıdır. Çalışma, DYY'nin belirleyicileri ile ilgili net bilgiye ulaşmanın zorluğu üzerinde durmaktadır. Root ve Ahmed (1979) ise, ülkenin sosyal durumunun, DYY'yi etkin olarak belirleyeceği görüşündedir. Sosyal durum ile ölçülmeye çalışılan beşeri sermayenin düzeyi, bireylerin refah seviyesi, sağlık sisteminin koşulları ve şehirleşme oranıdır. Schneider ve Frey (1985), çalışması ile beşeri sermayenin, ülkede işgücü niteliği ile ilgili fikir verdiğini belirterek DYY'yi etkilediğini ifade etmektedir. Böylece DYY'lerin ülke seçerken göz önünde bulunduracakları belirleyiciler oluşmaya başlamıştır.

Chakrabarti (2001), 135 gelişmiş ve gelişmekte olan ülkeyi kapsayan çalışmasında 1994 yılı için Leamer'in Bağlayıcı Uç Analizi yöntemini uygulamıştır. Çalışmada, yabancı yatırımların belirleyicileri arasında ev sahibi ülkedeki politik risk unsuru üzerinde durulmuştur. Politik istikrar düzeyi arttıkça ülkeye giriş yapan yabancı yatırım seviyesinde artış görülmektedir. Piyasa büyüklügünün ölçüldügü kişi başına düşen GSYIHH ile DYY arasındaki açıklayıcı 


\section{H.B.NUR - İ.DİLBER}

gücün oldukça yüksek olduğu tespit edilmiştir. Vergi oranları, ticari açıklık ve ekonomik büyüme ile DYY arasında pozitif, ücret, ithalat tarifeleri, net ihracat ve reel döviz kuru ile DYY arasında negatif ilişki bulunmuştur.

Asiedu (2002), çalışmasında, Sahraaltı Afrika ülkeleri ile diğer GOÜ’lerde DYY'yi etkileyen faktörler arasında farklılık olup olmadığını analiz edilmeye çalışılmıştır. 78 gelişmekte olan ülke, 1988-1997 dönemi için panel veri yöntemiyle incelenmiştir. Sahraaltı Afrika ülkelerine giriş yapan DYY, diğer GOÜ’lere göre daha düşük düzeyde kalmıştır. Çalışma bulgularına göre yatırımcıların, kıtadaki ülkeler hakkında yeterli bilgiye sahip olmaması, yatırım kararlarını olumsuz yönde etkilemektedir.

Nunnenkamp (2002), 1987-2000 yılları arasında, gelişmekte olan 28 ülke için, DYY'yi belirleyen değişkenlerin zamanla önemini koruyup korumadığını araştırmaktadır. Küreselleşme ile birlikte pazar kapasitesinin büyüklüğünün DYY'yi çeken önemli belirleyenlerden olduğu vurgulanırken, üretim faktörleri maliyeti ve dışa açıklık faktörlerinin etkisini yitirdiği belirtilmektedir.

Janicki ve Wunnava (2004), yatay kesit analizi ile Avrupa Birliği ülkeleri ile ve birliğe aday 8 Avrupa ülkesi için, 1997 yılı verileri ile çalışmaktadır. DYY'yi belirleyen faktörler arasında öne çıkan değişkenlerin pazar büyüklüğü, ve dışa açıklık ve birim emeğin maliyeti olduğu sonucuna ulaşmıştır.

DYY belirleyicileri ile ilgili Onyeiwu ve Shrestha (2004) tarafindan 29 Afrika ülkesi verisi ile 1975-1999 dönemi için bir çalışma yapılmıştır. Panel veri analizinin kullanıldığı araştırmada kullanılan değişkenler, büyüme oranı, enflasyon oranı, dışa açıklık ve doğal kaynak rezervlerine ulaşılabilirliktir. Araştırma ile yaygın kanaatin aksine Afrika'ya gelen DYY'de altyapı düzeyinin ve politik hakların önemli olmadığı sonucuna ulaşılmıştır.

Kök ve Açıkgöz Ersoy (2009), 1975-2005 döneminde 24 GOÜ için DYY ile kişi başına GSYIH ve brüt sermaye oluşumu değişkenlerinin pozitif ilişki gösterdiğini tespit etmektedir. Toplam borç servisinin GSYİH'ye oranı ile enflasyon oranı ise DYY'yi negatif olarak etkilemektedir. Çalışmada DYY'nin en 
etkin belirleyicisinin alt yapı değişkeni olan telefon ana hatlarının olduğu belirtilmektedir.

Özcan ve Ar1 (2010), 27 OECD ülkesi için, DYY belirleyicilerini, 1994-2006 dönemi verileri dinamik panel veri analizi kullanılarak, GMM tekniği ile sorgulanmaktadır. Çalışma sonucunda, DYY'yi büyüme oranı, altyapı düzeyi ve enflasyonun pozitif olarak etkilediği görülmüştür. Açıklık ve cari denge değişkenlerinin ise teoride beklenenin aksine DYY ile negatif ilişkili olduğu saptanmaktadir.

\section{EKONOMETRIKK MODEL VE VERİ SETİ}

Literatürle uyumlu biçimde, bu çalışmada panel veri analiz tekniği kullanılmaktadır. Çalışmada kullanılan ekonometrik model ile GOÜ’lere yönelik doğrudan yatırımları belirleyen faktörlerin, doğrudan yatırım üzerindeki göreceli etkilerinin öngörülmesi amaçlanmaktadır. Bu bağlamda, modelde, yalnızca ülke farklılıklarını ortaya koyan "yatay-kesit veri” kullanımının yerine, farklı ülkelere ait bilginin zaman içindeki değişimini de ortaya koyan panel veri kullanımı temel alınmaktadır. Panel veri analizinde tahminciler için kullanılan temel eşitlik aşağıdaki gibidir:

$$
y_{i t}=a_{i}+\beta_{i} x_{i t}+u_{i t}
$$

$\mathrm{Bu}$ eşitlikte; $i$ genel olarak ele alınan ekonomik karar birimini (firma, hane halk1, ülke gibi) yani yatay kesit birimlerini, $t$ ise zamanı ifade etmektedir. Bundan dolay1 $i$ indisi yatay kesit boyutu göstermekte, $t$ indisi ise zaman boyutunu belirtmektedir. $\alpha_{i}, t$ zaman ve $i$ yatay kesitine bağlı olarak tahmin edilen bireysel etkileri de kapsayan sabiti tanımlamaktadır.

\subsection{Panel Veri Seti}

Panel veri setine dahil edilen 18 gelişmekte olan ülke ${ }^{3}$, Uluslararası Para Fonu'nun (IMF) World Economic Outlook 2015 çalışmasından seçilmiştir.

\footnotetext{
${ }^{3}$ Arjantin, Brezilya, Bulgaristan, Çin, Çek Cumhuriyeti, Kolombiya, Yunanistan, Macaristan, Hindistan, Endonezya, Malezya, Meksika, Peru, Polonya, Romanya, Rusya, Güney Afrika, Türkiye.
} 


\section{H.B.NUR - İ.DİLBER}

Gelişmekte olan ülkeler grubuna dahil olan çok sayıda ülkeden seçim yapılırken, literatüre en çok konu olanlar dikkate alınmaya çalışılmıştır. Ayrıca her araştırmada olduğu gibi, hakkında yıllar bazında kesintisiz ve güvenilir veri bulunan ülkeleri alma zorunluluğu bu çalışmada da mevcuttur. Analizler, Gauss 10.0 ve Eviews 8.0 paket programları yardımıyla yürütülmüştür.

Doğrudan yabancı yatırımların ülkelere girişini belirleyen değişkenler, talep yönlü bir fonksiyon kullanılarak araştırılmaktadır. Bu amaçla, oluşturulan panel veri seti 12 değişken içermektedir. Veri seti yardımıyla doğrudan yabancı yatırımların temel belirleyicileri uzun dönemli eşitlikte incelenmektedir:

$$
\begin{aligned}
& F D I_{i t}=\alpha+\beta_{1} G D P_{i t}+\beta_{2} I N F_{i t}+\beta_{3} I N F R_{i t}+\beta_{4} O P E N_{i t}+\beta_{5} L A B_{i t}+ \\
& \beta_{6} G F C F_{i t}+\beta_{7} T E C H_{i t}+\beta_{8} D E B T_{i t}+\beta_{9} R E N T_{i t}+\beta_{10} C O R R_{i t}+\beta_{11} P R_{i t}+ \\
& \beta_{12} L A W_{i t}+\varepsilon_{i t}
\end{aligned}
$$

Analizde kullanılan 12 değişkenin 11'ine ait veriler yıllık olarak Dünya Bankası'nın "World Development Indicators (WDI)", Worldwide Governance Indicators (WGI) veri tabanından alınmıştır. Politik risk değişkenine ait veriler için ise Freedom House tarafindan yayınlanan sivil özgürlükler endeksinden yararlanılmıştır.

Literatürde DYY girişlerini açıklamak için çok sayıda değişken kullanılmaktadır. Çalışmamızın bu kısmında alınan değişkenler literatüre uyumlu olmakla birlikte veri derleme olanakları da gözetilerek seçilmiştir. Değişkenler hakkında kısa bilgi aşağıdaki şekilde belirtilmektedir.

Doğrudan Yabancı Yatırım (FDI): Uygulamamızın bağımlı değişkenidir. Ülkeye yapılan doğrudan yabancı yatırımların net giriş toplamının, GSYİH’ye oranını göstermektedir.

GSYIH (GDP): Temel belirleyicilerimizden “piyasa hacmi”nin etkisini temsil etmektedir. Piyasa hacminin ölçüsü olarak neredeyse standart uygulama GSYİH veya kişi başına GSYİH miktarının kullanılmasıdır. Bandera ve White (1968), Rott 
ve Ahmed (1979) çalışmalarında, söz konusu açıklayıcı değişkeni modellerine dahil etmiştir. Çalışma dahilinde seçilen ülkeler için 2005 baz yılına göre ABD doları cinsinden kişi başına GSYİH verileri kullanılmaktadır.

Enflasyon (INF): Enflasyon oranı çoğu zaman “ekonomik istikrar"ın bir ölçüsü olarak kullanılmaktadır. Çak ve Karakaş (2009) ile Özcan ve Arı (2010) ekonomik istikrarın varlığını bu değişken ile test etmektedir. Çalışmada enflasyon değişkeni için, Arjantin dışındaki diğer ülkelerin tüketici fiyatları endeksindeki yüzde değişim kullanılmaktadır. Arjantin için ulaşılamayan bu veri yerine, ülkeyi çalışmadan çıkarmamak adına GSYİH deflatörü kullanılmaktadır.

Altyapı (INFR): Evsahibi ülkede bulunan güçlü altyapının DYY çekmede belirleyici olduğu gözlenmektedir. Bu değişkeni açıklamak için enerji ve ulaştırma alanındaki kamu yatırımlarının bütçe içindeki payı, $\mathrm{km}^{2}$ ye düşen otoyol ve demiryolu ve her 100 kişiye düşen telefon hattı gibi veriler kullanılmaktadır. Çalışmamızda Asiedu(2006), Kirkpatrick vd. (2006), Kök ve Açıkgöz Ersoy (2009) ile Mike ve Oransay (2015)'in kullandığı gibi her 100 kişiye düşen telefon abonelikleri verileri kullanılmaktadır.

Dışa Açıklık (OPEN): Dış ticarette özgürlük sağlayan ülkelerin daha fazla DYY çekeceği düşünülmektedir. Dışa açıklığı DYY'nin belirleyicisi olarak el alan neredeyse tüm çalışmalarda değişken olarak dış ticaret hacminin, GSYIHH'ye oranı kullanılmaktadır. Bütün ülkelerde ulaşılması sorunsuz olan bu veri, aynı şekilde çalışmamızda açıklayıcı değişken olarak kullanılmaktadır.

İşgücü (LAB): İşgücü maliyetleri ile ilgili DYY belirleyicisi olan bu değişken literatürdeki en tartışmalı değişkendir. İşgücünün ucuz olmasının DYY'yi çektiği görüşünü benimseyenler ile aksine işgücünün ucuz olmasının değil eğitimli olmasının DYY çektiğini düşünenler farklı sonuçlar elde etmektedir. Çalışmamızda bu değişken ile ilgili ülkelerdeki toplam işgücü stoğu kullanılmaktadır. Ülkedeki işgücünün bol olması DYY'yi çeken faktörler arasında yer almaktadır.

Gayri Safi Sabit Sermaye (GFCF): Son y1llarda dünyadaki toplam DYY'nin yarısından fazlasını GOÜ’lerin çektiğini ve bu ülkelerin genel özellikleri arasında 


\section{H.B.NUR -İ.DÍLBER}

sermaye noksanlığ 1 çektiklerini hatırlarsak, sermaye yapısı zayıf olan ülkeler daha fazla yatırım almaktadır diyebiliriz. Bu değişken için gayri safi sabit sermayenin GSYİH'ya oranını gösteren verileri kullanmaktayız.

Teknoloji (TECH): Çalışmamızda kullanılan bu değişken ülkenin beşeri sermayesi hakkında bilgi vermesi amaçlı kullanılmaktadır. Yüksek teknoloji ihracatının toplam imalat sanayi ihracatı içindeki oranını gösteren veri seti ile ülkelerin eğitim ve işgücü kalitesi ölçülmek istenmektedir. Beşeri sermayenin gücü ile ülkeye giriş yapan DYY'nin arasındaki ilişkinin ölçülmesi hedeflenmektedir.

Borç (DEBT): GOÜ'lerin en belirgin özelliklerinden olan borç yükünü çalışmaya dahil ederek, DYY üzerindeki etkisi ölçülmeye çalışılmaktadır. Yüksek borç stoğu oranlarının yatırımcıyı daha güvensiz hale getireceği düşünülmektedir.

Doğal Kaynaklar (RENT): Doğla kaynaklar yönünden zengin olan ülkelerin DYY çekme konusunda avantajlı konumda olduğu görülmektedir. DYY'nin tarihsel olarak bakıldığında ilk çıkış noktalarından birinin gittiği ülkedeki doğal kaynakları kullanmak olduğu da bir gerçektir. Asiedu (2006) ile Onyeiwu ve Shrestha (2004) çalışmalarında DYY ile doğal kaynaklar arasında kuvvetli ilişki tespit etmektedirler. Çalışmamızda doğal kaynakları açıklayıcı değişken olarak toplam doğal kaynak kiralarının, GSYİH’ya oranı kullanılmaktadır.

Yolsuzluk (CORR): Bir ülkedeki yolsuzluk düzeyi arttıkça, ülkeye gelen DYY azalmaktadır. Habib ve Zurawicki (2002) ve Al-Sadig (2009) bu iki değişken arasında kuvvetli ilişki bulan çalışmaların sahipleridir. Bu değişkeni açıklamak adına çalışmamız dahilindeki ülkelerdeki yolsuzluk kontrolü tahminleri kullanılmaktadır.

Hukukun Üstünlüğ̈̆ $(\boldsymbol{L} \boldsymbol{A} \boldsymbol{W}): \quad$ Hukukun üstünlüğünden, yasaların uygulanmasının ötesinde, yerli-yabancı, küçük-büyük, hiçbir fark gözetilmeksizin bütün piyasa oyuncularına fırsat eşitliğinin sağlanması anlaşılmaktadır. Yabancı bir piyasaya giriş yapan firma için yerli firmalar ile rekabet edebilirlik açısından önemli bir belirleyicidir. Bu değişkeni açıklamak için Worldwide Governance 
Dokuz Eylül Üniversitesi İktisadi ve İdari Bilimler Fakültesi Dergisi Cilt:32, Sayl:2, Yll:2017, ss. 15-45

Indicators tarafından derlenen ülkelerdeki hukukun üstünlüğü tahminleri kullanılmaktadır.

Politik Risk (PR): Yatırım yapılacak ülkede politik anlamda istikrarın varlığı yatırımcı için önemli bir belirleyicidir. Yapılan farklı çalışmalarda grevle kaybolan işgücü sayısı, seçim yıllarına ait verilen kukla değişken ile ülkelerdeki kamulaştırma riski ölçümleri gibi farklı değişkenler kullanılmaktadır. Çalışmamızda, neredeyse tüm ülkeler için ölçülen ve Freedom House tarafından 1972 yılından itibaren yayınlanan sivil özgürlükler endeksi, veri havuzunun genişliği nedeniyle bu değişkenin açıklayıcısı olarak seçilmiştir. Endekste 1 ile 7 arasında değerler yer almaktadır. 1 değeri tam özgür bir ortamı, 7'ye doğru artan değerler ise özgürlüklerin giderek azaldığı bir yapıyı ifade etmektedir.

\subsection{Yatay Kesit Bağımlılığı Analizi}

Çalışma kapsamında 1996-2014 dönemini kapsayan 19 yıl (T) ile gelişmekte olan 18 ülke (N), CDLM1 ve CDLM2 testlerinin uygulanabilmesi için gerekli $\mathrm{T}>\mathrm{N}$ koşulunun gerçekleşmesini sağlamaktadır. $\mathrm{CD}_{\mathrm{LM} 1}, \mathrm{CD}_{\mathrm{LM} 2}$ ve $\mathrm{CD}_{\mathrm{LMADJ}}$ testlerinde, her ülkenin bireysel zaman etkisinden ayrı şekilde etkilenebildiği varsayımı altında tahminleme yapılmaktadır. Yatay kesit bağımlılı̆̆ı test sonuçları Tablo 2.'de tablolaştırılmaktadır.

Tablo 2.Yatay Kesit Bağımlılığı Test Sonuçları

\begin{tabular}{|c|c|c|c|c|c|c|c|}
\hline & $F D I$ & $G D P$ & $I N F$ & INFR & OPEN & $L A B$ & $\overline{G F C F}$ \\
\hline$C D_{L M 1}$ & $88.265^{*}$ & 97.363* & 113.692* & 221.983* & $145.323 *$ & 74.953* & 93.774* \\
\hline$C D_{L M 2}$ & 8.967* & 9.804* & 10.370* & $11.253 *$ & 21.243* & 9.853* & 19.834* \\
\hline$C D_{L M A D J}$ & 21.839* & $24.918 *$ & 19.83* & 32.553* & 24.534* & $16.935 *$ & 33.253* \\
\hline & $R E N T$ & CORR & $P R$ & $L A W$ & TECH & $\overline{D E B T}$ & \\
\hline$C D_{L M 1}$ & $139.464 *$ & $191.483 *$ & $113.883 *$ & 99.542* & 101.543* & 154.198* & \\
\hline$C D_{L M 2}$ & $13.754 *$ & 22.201* & $15.581 *$ & 11.242* & 6.738* & $15.292 *$ & \\
\hline
\end{tabular}




\section{H.B.NUR -İ.DİLBER}

\begin{tabular}{|l|c|c|c|c|c|c|}
\hline$C D_{\text {LMADJ }}$ & $27.473 *$ & $48.231 *$ & $24.224 *$ & $15.642 *$ & 17.293 & $12.484 *$ \\
& & & & & & \\
\hline
\end{tabular}

Not:*, yatay kesit bağımlılı̆̆ını göstermektedir.

$\mathrm{CD}_{\mathrm{LM} 1}, \mathrm{CD}_{\mathrm{LM} 2}$ ve $\mathrm{CD}_{\mathrm{LMADJ}}$ testlerinin sonucu, ülke panel veri setlerinde boş hipotez istatistiki olarak anlamlı şekilde reddedilmekte ve yatay kesit bağımlılığının varlığı kanıtlanmaktadır.

\subsection{Eşbütünleşme Analizi}

Ekonometrik analizler sonucunda panel veri setinde, yatay kesit bağımlı̆̆ olduğu ve mixed serilerden oluştuğu sonucuna ulaşılmaktadır. $\mathrm{Bu}$ nedenle, modelde eşbütünleşik bir ilişkinin olup olmadığını test etmek için Westerlund (2006) testi uygulanmaktadır. Westerlund (2006) eşbütünleşme testi, bir LM istatistiği testidir. Yapısal kırılmayı, yatay kesit bağımlılı̆̆ını dikkate alan ve doğrusal olmayan serilerde de uygulanabilen bir testtir. Testin uygulamasında Case $=4$ (bireysel sabit ve trend varken yapısal kırılmayı dikkate alır) varsayımı tahminlenmektedir. Maksimum gecikme sayısının 3 ve döngü sayısının 1.000 olarak alınması sonucu ulaşılan sonuçlar, aşağıda tablolaştırılmaktadır. Tablo 3., eş bütünleşme analizi sonuçlarını göstermektedir.

Westerlund (2006) eşbütünleşme testinde, yatay kesit bağımlılığının dikkate alındığ 1 Olasılık ${ }^{2}$ sonucuna göre, modelde gelişmekte olan ülke panel veri setinde boş hipotez olan eşbütünleşme vardır, istatistiki olarak anlamlı şekilde kabul edilmektedir.

Tablo 3. Eşbütünleşme Testi Sonuçları

\begin{tabular}{|c|c|c|}
\hline & Test & Eşbüitünleşme Testi \\
\hline Kırılmasız & Değer & 11.839 \\
\hline & Olasıllık $^{1}$ & 0.008 \\
\hline & Olasıllı $^{2}$ & $0.976^{*}$ \\
\hline Kırılmalı & Değer & 44.392 \\
\hline & Olasıllık $^{1}$ & 0.041 \\
\hline & Olasılık $^{2}$ & $0.994^{*}$ \\
\hline
\end{tabular}


Dokuz Eylül Üniversitesi İktisadi ve İdari Bilimler Fakültesi Dergisi

Cilt:32, Sayl:2, Yll:2017, ss. 15-45

Notlar: Olasılık ${ }^{1}$ asimtotik normal dağılımına bağlı olarak tahminleme yapmaktadır. Olasılık ${ }^{2}$ özçıkarım (bootstrapped) dağılımına bağlı olarak tahminleme yapmaktadır. *, istatistiki olarak anlamlı eşbütünleşme varlığını göstermektedir.

\subsection{Uzun Dönem Katsayıları Tahmini}

Uzun dönem katsayılarına ulaşmak için uygulanan diğer bir ekonometrik yöntem, Panel ARDL (Autoregressive Distributed Lag) modelidir. Bu modeli tahmin etmek için Pesaran vd. (2004) tarafindan geliştirilen, PMGE (Pooled Mean Group Estimation) ve MGE (Mean Group Estimation) tahmincileri kullanılmaktadır. Model tahmin edilirken PMG veya MG tahmincilerinin tutarlılığını test etmek için, Hausman testi uygulanmaktadır. Tablo 4. çalışmaya temel oluşturan soruların cevaplarına ilişkin katsayıları göstermektedir.

Tablo 4. PMG ve MG Testi Sonuçları

\begin{tabular}{|c|c|c|c|}
\hline & PMG & MG & Hausman Test \\
\hline Uzun dönem Katsayıları & & & \\
\hline GDP & $-0,0002$ & 0.0089 & 0.76 \\
\hline INF & 0.0387 & 0.5843 & 0.44 \\
\hline INFR & -0.7683 & 0.9423 & 0.78 \\
\hline OPEN & 0.1301 & 0.4456 & 0.81 \\
\hline LAB & 0.7683 & 0.9842 & 0.65 \\
\hline GFCF & -0.0150 & 0.4322 & 0.32 \\
\hline TECH & 0.5218 & 0.4298 & 0.96 \\
\hline DEBT & -0.3014 & -0.4590 & 0.52 \\
\hline RENT & 0.0261 & 0.7821 & 0.92 \\
\hline CORR & 0.8867 & 0.7719 & 0.88 \\
\hline PR & 0.8105 & 0.7313 & 0.27 \\
\hline LAW & 0.6239 & 0.5624 & 0.38 \\
\hline
\end{tabular}

Hausman testi sonucunda (Hausman test istatistiği $=0.89$ ), gelişmekte olan ülkelerde boş hipotez ve hem PMG hem de MG tahmincisinin tutarlılı̆̆ kabul edilmektedir, fakat sadece PMG etkin tahmincidir (Baltagi, 2008; 72). Negatif işaretli ve istatistiksel olarak anlamlı hata düzeltme katsayısı (Ø), bağımlı ve bağımsız değişkenler arasında uzun dönemli bir ilişkinin olduğunu ve dengeden 


\section{H.B.NUR -İ.DİLBER}

sapılsa bile tekrar dengeye yakınsandığını göstermektedir. $\mathrm{Bu}$ katsayıyla, gelişmekte olan ülkelerde doğrudan yabancı yatırımların sürdürülebilir olduğu sonucu ortaya çıkmaktadır. Tablo 4'deki tanısal testlerden elde edilen sonuçlara göre, modelde herhangi bir otokorelasyon ve heteroscedasticity problemi bulunmamaktadır. DYY modeli için ulaşılan uzun dönem katsayılarının tümü istatistiksel olarak anlamlıdır. Uzun dönem katsayılarının yorumlanması ile analizimiz anlam kazanacaktır. Tablo 4'de gösterilen PMG değerlerinin etkin tahminciler olması nedeniyle, yorumlamalar bu değer üzerinden yapılacaktır.

Çalışmada, DYY'yi etkileyen en güçlü değişken yolsuzluk kontrolü tahminleridir. GOÜ’de yolsuzluk kontrolü \% 1 yükseldiğinde, yapılan DYY miktarı \% 0.89 artmaktadır. Yolsuzluk, rüşvet verme/alma alışkanlıklarının yüksek olduğuna ve kurumsal yapıların kalitesizliğine işaret etmektedir. Ekonomilerde adil ve etkin piyasaların gelişmesini engellemektedir. Piyasaya girişlerde, rüşvetin ön koşul olması nedeniyle fiyat ve kalite daha az önem taşımaya başlayacakken, malların fiyatları rakip piyasalara göre daha yüksek seyredecektir. Yolsuzluk düzeyi artan ekonomilerde, yatırımcı için yatırım riski artmakta ve güvensizlik oluşmaktadır. Evsahibi ülkeler için yolsuzluk kontrol edilebildiği ve önlem alınabildiği sürece DYY çekmek daha kolaylaşacaktır.

İkinci olarak DYY’yi etkileyen faktör, politik risk faktörüdür. Politik risk varlığının, ülkeye giren DYY'yi azaltacağı yönündeki beklenti dahilinde uzun dönem katsayısının negatif çıkması gerekmektedir. Ancak sivil özgürlükler endeksinin kullanıldığı veri setine göre, GOÜ’lerde politik riskin \% 1 artışında, DYY \% 0,81 artmaktadır. Kar ve Tatlısöz (2008) benzer bir sonuç bulurken, Karagöz (2007) politik riskin DYY üzerinde etkili olmadığı sonucuna ulaşmaktadır. Teori ile uyumsuz ancak istatistiki olarak anlamlı olan bu sonuca göre, GOÜ’lerde gerek kurumsal yapının noksanlığı gerekse işçi haklarının yeterince korunmadığı bir ortamda yabancı yatırımcının daha rahat hareket ettiği gibi bir kanıya varılmaktadır.

İşgücü değişkeni, DYY üzerinde etkili bir sonuç vermektedir. Ülkedeki işgücü stoğu \% 1 arttığında, ülkeye gelen DYY \% 0,76 artış göstermektedir. İşgücü 
değişkeni literatürdeki tartışmalı değişkenlerden bir tanesidir. İşgücünün bol ve ucuz olduğu ülkelerin daha çok DYY çektiği görüşü ile aksine eğitimli ve kalifiye işgücünün varlığının daha çok DYY çektiği görüşü karşımıza çıkmaktadır. Ayrıca işgücü maliyetlerinin, toplam maliyetler içinde düşük düzeyde kalıyor olması da işgücü değişkeninin DYY üzerinde etkili olmayacağı görüşünü doğurmaktadır. Analizimizden çıkan sonuca göre işgücünün bol olduğu yani ücretlerin düşük düzeyde kaldığg GOÜ’de DYY artmaktadır. Bu sonuç Schneider ve Frey (1985) ile Bevan ve Estrin (2004)'in çalışmaları ile aynı yöndedir.

Hukukun üstünlüğü tahminleri ile ele alınan değişkendeki \%1 birimlik artış, DYY'yi \% 0,62 arttırmaktadır. Bu yönde pozitif ve güçlü bir etki beklenen bir sonuçtur. Yabancı yatırımcı açısından ev sahibi ülkedeki hukuki yapının sağlamlığı, kurumsal yapının kaliteli oluşu önemli belirleyicilerdendir. Düşük kalitedeki yasal koruma, kamulaştırma politikalarında yaşanan sürekli değişim ve kurumlar arasındaki koordinasyon eksikliği yabancı yatırımcının aradığı güven ortamını bulmasını engelleyecektir. Bu nedenle yabancı yatırım mevzuatları özenle gözden geçirilmeli, kuruluş işlemlerinin uzun ve zahmetli oluşu ortadan kaldırılmalıdır. GOÜ'in bürokrasi ile yatırımcıya yüklediği ağır yük gerekli düzenlemeler ile giderilmelidir.

Teknoloji değişkeni adı altında kullandığımız imalat sanayi ürünleri ihracatı içinde ileri teknoloji ürünlerinin ihracat payı verisini çalışmaya alarak ülkede mevcut beşeri sermayenin kalitesi ile ilgili fikir sahibi olmaya çalışılmaktadır. Literatürde beşeri sermaye ile ilgili rastlanan veri, lise mezunu kişi sayısı olmaktadır. Ancak bu verinin, genel olarak GOÜ'lerdeki okullaşma yapısı dikkate alındığında, sağlıklı sonuç vermeyeceği düşünülmektedir. İleri teknoloji ihracatı payının bir ülkede artıyor olması, o alanda çalışan kalifiye işgücü sayısının da doğru orantılı olarak arttığ 1 anlamına gelmektedir. Analiz sonucuna göre söz konusu verideki \% 1'lik artış, DYY'yi \%0,52 arttırmaktadır. Çıkan bu katsayıyı işgücünün ölçüldüğg̈ katsayı ile karşılaştırıldığında $(0,76)$, iki değerin birbirine yakın olduğu görülmektedir. Gelişmekte olan ülkelerde halen işgücü maliyetinin daha düşük olmasının daha çok DYY çektiğini yorumlamakla beraber, beşeri 


\section{H.B.NUR - İ.DİLBER}

sermayeyinin ölçüldügü değişkenin de pozitif ve toplam işgücü verisine yakın bir değerde çıkması, önümüzdeki yıllarda yüksek beşeri sermayenin ülkelere DYY çekmede ön sıralarda yer alacak bir belirleyici olacağına işaret etmektedir.

DYY ile aralarında güçlü olmasa da pozitif bir ilişkinin olduğunu gördüğümüz değişken ülkenin dışa açıklığıdır. Dış ticaret hacminin, GSYİH’ye oranıyla ölçülen dışa açıklık oranındaki \% 1'lik artış DYY'yi \% 0,13 arttırmaktadır. Bulunan bu sonuç Kravis ve Lipsey (1982) ve Culem (1988) ile aynı yöndedir (Chakrabarti, 2001:100). Yaprakl1 (2006) ve Lebe ve Ersungur (2011) ile aynı yöndedir. Teoride de genel olarak dış ticaret serbestliği olan ülkeler, kısıtlayıcı ticaret politikaları olan ülkelere kıyasla daha çok DYY çekmektedir.

Doğal kaynakların DYY üzerindeki etkisini ölçtüğümüz toplam doğal kaynak kiralarının GSYIH'ye oranı verisi ile DYY girişi arasında pozitif bir ilişki tespit edilmektedir. Ancak katsayı 0,027 gibi düşük bir düzeydedir. Teoride, doğal kaynak açısından zengin ülkelerin aynı gelişme düzeyinde yer alan ancak kaynakları kıt olan ülkelere göre daha fazla DYY çektiği görülmektedir. Katsayının oldukça düşük çıkması ise doğal kaynakların DYY üzerindeki belirleyiciliğinin düşük olduğunu göstermektedir. Bunun nedeni, örnek ülkelerimizin büyük ölçüde kaynağa bağımlı ülkeler olmamasıdır.

Altyapı değişkenine ait katsayının teoride beklenenin aksine negatif çıktığ 1 görülmektedir (-0,77). Literatüre uygun olarak bu değişkenle ilişkili olarak her 100 kişiye düşen telefon abonelikleri verisi ile çalışılmaktadır. Bu değişkeni kullanan diğer çalışmalardan Kök ve Ersoy (2009) ile Özcan ve Arı (2010) altyapı ile DYY girişi arasında pozitif ilişki tespit etmiştir. Çalışmamızda katsayının negatif çıkmasını son yıllardaki teknolojik değişim ile sabit telefon hatlarının hızla yaygınlığını kaybetmesiyle açıklayabiliriz.

Negatif ilişki bulduğumuz diğer değişkenler arasında gayri safi sabit sermaye ($0,015)$ ve borç stoğu $(-0,3)$ bulunmaktadır. Son yıllarda GOÜ'lere giden DYY'nin artış gösterdiği görülmektedir. Sermaye yapısının zayıf olması GOÜ’ler açısından temel bir özelliktir. Sermaye yapısını gösteren değişken ile DYY girişi arasındaki 
ilişkinin negatif çıkması GOÜ'lere giden DYY'nin artış göstermesiyle açıklanabilir. Evsahibi ülkede borçluluğun yüksek oluşu ise yatırımcı için cazip görünmemektedir.

\section{SONUÇ}

Dünya ölçeğinde 2014 yılında, doğrudan yabancı yatırım akımlarının yarısından çoğunun gelişmekte olan ülkelere yönelmesi, DYY'yi ülkelere çeken belirleyicilerin neler olduğuna yönelik merakı daha da arttırmıştır.1996-2014 dönemine ait verilerle yapılan panel veri analizinde, tüm değişkenler ekonometrik olarak anlamlı sonuçlar vermiştir. Yolsuzluk kontrolü, dışa açıklık oranı, teknoloji, toplam işgücü ve hukukun üstünlüğü değişkenlerinin DYY girişlerini olumlu yönde etkilediği görülürken, borç stoğu, gayri safi sabit sermaye ve alt yapı değişkenin ise DYY girişlerini olumsuz yönde etkilediği sonucuna varılmaktadır.

Gelişmekte olan ülkelerin kalkınma çabalarında doğrudan yabancı yatırımlara olan ihtiyaçları da göz önünde bulundurulduğunda yapılan analizin sonuçları oldukça önem taşımaktadır. GOÜ'lerin öncelikle hukuki ve idari altyapılarını kuvvetlendirmeye ve yolsuzluk düzeylerini azaltmaya yönelik tedbirler almaları gerekmektedir. Evsahibi ülkede şeffaflığın sağlanmamış olması, gereksiz bürokratik işlemler, güvenilir yasal düzenlemelerin olmayışı doğrudan yabancı yatırımcıyı uzaklaştıran en önde gelen etmenler arasındadır.

DYY girişini arttırmak isteyen ülkelerde, emek yoğunluğunun bulunması DYY girişi sağlamada temel bir belirleyici olarak önemini korumaktadır. Ancak beşeri sermayenin arttırılarak teknoloji yoğun yatırımların da önünün açılması gerekmektedir. Çünkü yatırımcılar, teknolojiyi kullanabilecek yetkinlikte alt yapı ve kurumların yanı sıra eğitimli işgücüne de ihtiyaç duymaktadır. Teknolojik etkinlikten uzak olmak verimliliğin düşük gerçekleşmesinin kabulüne neden olmaktır. Bu durum üretim maliyetlerini arttıracaktır. Ayrıca GOÜ'lerin teknoloji yaratamıyor olması onları hiç kullanamayacakları anlamına gelmemektedir. DYY sayesinde ülkedeki üretim süreçlerinde kullanılan teknoloji, ülke vatandaşlarının teknik bilgiyi uygulayarak edinmeleri firsatını doğuracaktır. 


\section{H.B.NUR - İ.DİLBER}

Çalışmada elde edilen bulgular UNCTAD'ın 2005 Dünya Kalkınma Raporu'nun bulguları ile uyum göstermektedir. İyi bir yatırım ortamının nasıl olması gerektiği konusuna ayrılan rapor, 53 gelişmekte olan ülkede binlerce firmaya yönelik anketler ile sonuçlar elde etmiştir. Yatırım ortamını olumsuz etkileyen başlıca unsur, ilan edilen politikaların uygulama belirsizliği yanında yasaların da uygulama belirsizliği içinde olmasıdır. Önem sırasına göre devam eden unsurlar; yatırım riskini yükselten makro düzeyde istikrarsızlık, yüksek ve belirsiz vergi oranları, yolsuzluk ve rüşvet, finansman olanaklarının sınırlı olması, suç oranlarının yüksek olması, adaletsiz vergi sistemi, eğitimli işgücü eksikliği ve güvenilir olmayan yasal sistemin varlığıdır.

DYY çekmek adına gelişmekte olan ülkelerin giriştikleri rekabetten başarı kazanarak çıkmanın formülü, ilk başta ekonomik, politik ve kurumsal yapıların yeniden düzenlenmesinden geçmektedir. Gelişmekte olan bir ülke makro ekonomik göstergelerinde istikrarlı bir gelişme gösterdiği zaman, piyasanın genişlemesi ile birlikte ölçek ekonomilerinden yararlanabilecek ve verimli kaynak kullanımı sağlayarak doğrudan yatırım girişlerini özendirebilecektir. Ülkenin dışa açıklık derecesi yükseldikçe de potansiyel yatırımcıların ülkeye olan ilgisinin artması beklenecektir.

\section{KAYNAKÇA}

AGARWAL, J. P., (1980), "Determinants of Foreign Direct Investment: A Surve", Weltwirtschaftliches Archiv, 116(4): 739-773.

AL-SADIG, A. (2009), "The Effects of Corruption on FDI Inflows", Cato Journal, 29(2): 267-294.

ASIEDU, E. (2002), "On the Determinants of Foreign Direct Investment to Developing Countries: Is Africa Different?". World Development. 30 (1): 107-119.

ASIEDU, E. (2006), "Foreign Direct Investment in Africa: The Role of Natural Resources, Market Size, Government Policy, Institutions and Political Instability", The World Economy, 29(1): 63-77. 
Dokuz Eylül Üniversitesi İktisadi ve İdari Bilimler Fakültesi Dergisi Cilt:32, Sayl:2, Yll:2017, ss. 15-45

BAlTAGI, B. H. (2008), Econometric Analysis of Panel Data. Chichester. John Wiley and Sons Ltd. 4th Edition.

BAL, H. VE GÖZ, D. (2010), "Doğrudan Yabancı Sermaye Yatırımları ve Türkiye”, Ç.Ü. Sosyal Bilimler Enstitüsü Dergisi, 19 (2):450-467.

BANDERA, V.N., WHITE, J.T. (1968), U.S. "Direct Investments and Domestic Markets in Europe", Economica Internazionale, 21:117- 133.

BATMAZ, N. ,TUNCA H. (2005), Doğrudan Yabancı Sermaye Yatırımlart ve Türkiye (1923-2003), Beta, İstanbul.

BEVAN, A.A., ESTRIN, S. (2004), "The Determinants of Foreign Direct Investment into European Transition Economies", Journal of Comparative Economics. 32: 775-787.

BREUSCH, T. S., PAGAN, A. R. (1980), "The Lagrange Multiplier Test and Its Applications to Model Specification in Econometrics", Review of Economic Studies, 47 (1):239-253.

CHAKRABARTI, A.(2001), “ The Determinants of Foreign Direct Investment: Sensitivity Analyses of Cross-Country Regression" Kyklos, 54(1):89-114.

ÇAK, M., KARAKAŞ, M. (2009), “ Doğrudan Yabancı Sermaye Yatırımlarını Belirleyen Unsurlar ve Etkileri”, Marmara Üniversitesi İBF Dergisi, 26 (1):43-54.

DPT.(2000), "Doğrudan Yabancı Sermaye Yatırımları Özel İhtisas Komisyonu Raporu. VIII. Beş Yıllık Kalkınma Planı" Yayın No: DPT:2514-ÖIK:532, Ankara. www.kalkinma.gov.tr $(12.02 .2013)$.

DUNNING, J.H. (1988), Explaining International Production. Unwin Hyman, London.

DUNNING, J.H. (1981), "Explaining the International Direct Investment Position of Countries: Towards a Dynamic or Developmental Approach", Weltwirtschaftliches Archiv, 117: 30-64. 


\section{H.B.NUR - İ.DİLBER}

EROĞLU, N. (2002), Küreselleşme: Iktisadi Yönelimler ve Sosyopolitik Karşıtlıklar, Om Yayınevi, Derleyen: Aklan Soyak, İstanbul.

HABIB, M., ZURAWICKI L. (2002), "Corruption and Foreign Direct Investment”, Journal of International Business Studies, 33(2):291-307.

HADRI, K., KUROZUMI, E. (2012), “A Simple Panel Stationarity Test in The Presence of Serial Correlation and A Common Factor", Economics Letters, 115:3134.

IM, K. L., PESARAN, M. H., SHIN, Y. (2003), "Testing for Unit Roots in Heterogeneous Panels", Journal of Econometrics, 115: 53-74.

IMF (2015), "World Economic Outlook Ekim 2015: Adjusting to Lower Commodity Pricesworld", International Monetary Fund, Publication Services. Washington, $A B D$. https://www.imf.org/external/pubs/ft/weo/2015/02/pdf/text.pdf, (18.11.2015)

JANICKI, H.P., WUNNAVA, P.V.(2004), "Determinants of Foreign Direct Investment: Empirical Evidence From EU Accession Candidates", Applied Economics, 36: 505-509.

KAR, M., TATLISÖZ, F. (2008), “ Türkiye'de Doğrudan Yabancı Sermaye Hareketlerini Belirleyen Faktörlerin Ekonometrik Analizi”, KMU IIIBF Dergisi, 10 (14): $1-23$

KARAGÖZ, K. (2007), "Türkiye'de Doğrudan Yabancı Yatırım Girişlerini Belirleyen Faktörler: 1970:2005”, Journal of Yasar University. 2(8): 927-948.

KIRKPATRICK, C., PARKER D.,ZHANG, Y. (2006), "Foreign Direct Investment in Infrastructure in Developing Countries: Does Regulation Make a Difference?", Transnational Corporation, 15 (1): 143-171.

KÖK R.,AÇIKGÖZ B. (2009), "Analyses of FDI Determinants in Developing Countries", International Journal of Social Economics, 36 (1/2): 105-123. 
LEBE, F. S., ERSUNGUR M. (2011), “Türkiye'de Doğrudan Yabancı Sermaye Yatırımını Etkileyen Ekonomik Faktörlerin Ampirik Analizi” Atatürk Üniversitesi İBF Dergisi 10. Ekonometri ve İstatistik Sempozyumu Özel Saylsl, 2011: 321-339.

LEVIN, A., LIN, C. F. VE CHU, C. J. (2002), "Unit Root Tests in Panel Data: Asymptotic and Finite Sample Properties", Journal of Econometrics, 108:1- 24

MIKE, F., ORANSAY G. (2015), Altyapı ve İnovasyon Değişimlerinin Doğrudan Yabanc1 Yatırımlar Üzerine Etkisi: Türkiye Üzerine Ampirik Bir Uygulama, Akademik Sosyal Araştırmalar Dergisi, 3 (12): 372-381.

NUNNEKAMP, P. (2002), "To What Extent Can Foreign Direct Investment Help Achieve International Development Goals?", Kiel Institute for World Economics, 1128:1-50.

OECD (2008), "Benchmark Definition of Foreign Direct Investment Fourth Edition"

http://www.oecd.org/daf/inv/investmentstatisticsandanalysis/40193734.pdf (23.05.2013).

ONYEIWU, S., SHRESTHA H. (2004), "Determinants of Foreign Direct Investment in Africa", Journal of Developing Societies, 20 (1-2): 89-106.

ÖZCAN, B., ARI, A. (2010), "Doğrudan Yabancı Yatırımların Belirleyicileri Üzerine Bir Analiz: OECD Örneği” İstanbul Üniversitesi Iktisat Fakültesi Ekonometri ve İstatistik Dergisi, 12/2010: 65-88.

PESARAN, M. H., SHIN, Y.,SMITH, R. J. (1999), "Pooled Mean Group Estimation of Dynamic Heterogeneous Panels", Journal of the American Statistical Association, 94:621-634.

PESARAN, M. H. (1997), "The Role of Economic Theory In Modelling The Long Run”, The Economic Journal,107 (440):178-191.

PESARAN, M. H. (2007), "A Simple Panel Unit Root Test in The Presence of Cross-Section Dependence" Journal of Applied Econometrics,22:265-312. 


\section{H.B.NUR - İ.DİLBER}

PESARAN, M. H. (2004), "General Diagnostic Tests For Cross Section Dependence in Panels", Cambridge Working Papers in Economics Working Paper 1229:1-43.

PESARAN, M. H., YAMAGATA, T. (2008), "Testing Slope Homogeneity in Large Panels" Journal of Econometric, 142 (1):50-93.

ROOT, F. VE AHMED, A. (1979), “ Empirical Determinants of Manufacturing Direct Foreign Investment in Developing Countries, Economic Development and Cultural Change, 27:751-767.

ROSENSTEIN- RODAN, P.N. (1961), "International Aid For Underdeveloped Countries. Center For International Studies. Massachusetts Institute of Technology",Cambridge.

https://dspace.mit.edu/bitstream/handle/1721.1/83066/14907684.pdf?sequence=1 (11.03.2013).

SCHNEIDER, F., FREY, B. (1985). "Economic and Political Determinants of Foreign Direct Investment," World Development, 13: 161-175.

SEYİDOĞLU, H. (2001), Uluslararası Finans. Güzem Yayınları. Geliştirilmiş 3. Bask1 No:16. İstanbul.

UNCTAD, (1998), "World Investment Report 1998. Trends and Determinants", United Nations New York and Geneva, http://unctad.org/en/Docs/wir1998 en.pdf (12.02.2014).

UNCTAD, (2005), "World Investment Report 2005 Transnational Corporations and the Internationalization of R\&D", United Nations New York and Geneva,http://unctad.org/en/docs/wir2005_en.pdf (8.03.2015).

UNCTAD, (2007), “ World Investment Report 2007”, Transnational Corporations, Extractive Industries and Development. United Nations New York and Geneva.http://unctad.org/en/docs/wir2007_en.pdf (8.03.2015). 
UNCTAD, (2008), "World Investment Report 2008. Transnational Corporations, and the Infrastructure Challenge", United Nations New York and Geneva.http://unctad.org/en/docs/wir2008_en.pdf (8.03.2015).

UNCTAD, (2011), “World Investment Report 2011. Non-Equity Modes of International Production and Development" United Nations New York and Geneva, http://unctad.org/en/PublicationsLibrary/wir2011_en.pdf (8.03.2015).

UNCTAD, (2012), "World Investment Report 2012. Towards a New Generation of Investment Policies", United Nations New York and Geneva.http://unctad.org/en/PublicationsLibrary/wir2012_embargoed_en.pdf (8.03.2015).

UNCTAD, (2013), "World Investment Report 2013 Global Value Chains: Investment and Trade for Development" United Nations New York and Geneva, http://unctad.org/en/PublicationsLibrary/wir2013_en.pdf (8.03.2015).

UNCTAD, (2015), “World Investment Report 2015. Reforming International Investment Governance", United Nations New York and Geneva, http://unctad.org/en/PublicationsLibrary/wir2015_en.pdf (8.03.2015).

WESTERLUND, J. (2006), "Testing for Panel Cointegration with Multiple Structural Breaks", Oxford Bulletin of Economics \& Statistics, 68:101-32.

WESTERLUND, J. (2007). "Testing for Error Correction in Panel Data" Oxford Bulletin of Economics and Statistics,69(6):709-748.

YAPRAKLI, S. (2006), "Türkiye'de Doğrudan Yabancı Yatırımların Ekonomik Belirleyicileri Üzerine Ekonometrik Bir Analiz", D.E.Ü. İI.B.F. Dergisi, 21 (2): $33-48$.

YASED, (2013)," Uluslararası Doğrudan Yatırımlar Değerlendirme Raporu2012 Y1lsonu" No:4. http://www.yased.org.tr/ (17.02.2015). 